ISSN: 2455-104X

Volume 5,Issue 2 (July-Dec) 2019,14-20

Paper ID: IJRLS-1295

\title{
ELECTRONIC BOOK USAGE AND INSTITUTIONAL READINESS IN UNIVERSITY LIBRARIES IN NIGERIA
}

\author{
Dr. Evarest C. Madu \\ Department of Library Information Technology \\ School of information and Communication Technology, \\ Federal University of Technology, Minna, Nigeria \\ E-mail:evamadu@yahoo.co.uk
}

\section{ABSTRACT}

This study examined the readiness and use of electronic books for information service provision in university libraries in Nigeria. Survey research design was adopted while a multi-stage sampling technique was used to select two universities from each of the six geopolitical zones based on electronic books presence in the university libraries. Questionnaire was used as instrument for data collection, while data collected were analysed with the use of descriptive statistics. Findings revealed that the level of institutional readiness is low, while majority of the respondents agreed that electronic books are useful for information service provision. The study recommended that they universities should increase financial resources available to the university libraries in the area of ICT facilities acquisition among others.

Keywords: Institutions, University, Library, Electronic, Books, Information, Readiness, Services

\section{INTRODUCTION}

Education as we have it today has been greatly influenced by rapid advances made in technology in the cotemporary educational environment. The changes affect not only the methods of teaching but also the resources used in teaching and learning and information provision in the libraries.

One of these charges is manifested in electronic or e-book. According to [1]an Electronic -book is a book in electronic format. The electronic nature of e-book makes it easy to be downloaded to a computer, laptop, smartphones and any other kind of reading devices. They are read on the screen as they can only be machine readable. After downloading from the internet, e-books can be read offline and easily printed.

In a research on the definition of e-book by [2], e-book is defined to include "reference to; the digital or electronic nature of ebook, analogy to printed book, some indications of the content of e-book and some allusion to e-book technologies.

Simplifying the concept of e-book[3]argued that an e-book is an electronic version of a traditional printed book that can be read with the use of a personal computer or by using an e-book reader. The definition also includes any book that is capable of being read on a computer or any electronic device including tablet, smartphone, laptop etc.

In our contemporary educational system, academic libraries which include those libraries in the universities, polytechnic, colleges of education now acquire e-book to complement the traditional printed books in the libraries according to [4], e-book 
has now become a standard platform in providing reading materials. In universities, financial resources are now being spent in procuring the electronic books thereby making the library more attractive as clients with information technology background find it very convenient to use in the pursuit of their academic activities. The electronic books offer some benefits and advantages which look irresistible to the user of modern day library. In the work of [1], the following benefits and advantage of e-books, were outlined.

1. E-books are delivered almost instantaneously. You can purchase, download and start reading them within minutes, without leaving your chair. You don't have to go to bookstores to buy them, neither wait for them for days, weeks and sometimes more to arrive in the mail.

2. No trees are required to manufacture paper for the pages of e-books

3. When you need certain information, you can get it immediately, by downloading an e-book

4. Many e-books are sold nowadays with bonuses, which you usually do not get with a printed book. This adds value to your purchase.

5. E-books take up less space. You practically don't need any space to store them. You don't need a library or a room for them. You can store hundred and thousands of e-books on your computer or reading device.

6. E-books are portable. You can carry a whole library of hundreds of books with you, on CD, in a laptop, notebook or any e-book or any e-book reader, without worrying about their weight.

Writing on the effects of e-book with regard to change in the access to information,[4], arguedthat with electronic books, information now transcends beyond the boundaries and is available and accessible at any time. It is now a veritable tool that augments books and any reading material.

Electronic books have been a tremendous assistance to distance learning programe. The National Open University of Nigeria NOUN, and University of Ibadan Distance Learning programme operate mainly on wireless network expansion, mobile technologies and ability to purchase e-books in consortia. Students now purchase and download e-books through the internet after payment are made, students are now directed to the necessary page. Some also receive link in an e-mail. Once the link is clicked, the e-book will be automatically downloaded to your computer in a pre-determined folder of your choice. You can read the material on-line or offline, hard copy can also be printed.

On the lure of the e-books, [6], argued that e-books are enormously attractive to very large and important academic communities largely untouched by the arrival of e-journal, which has revolutionized the information seeking behavior of many academics, scientists and researchers in particular.

Writing on the origin of e-books, Yaya cited in [7] argued that e-books were books originally published in a traditional way, and then digitized for use as an electronic book or they can be books that were written purposely for the digital market. By the nature of e-books, they are all machine readable. Specific machine called e-book readers are used to make them readable.

In Nigerian University system the emergency and integration of e-book in the collection of the university libraries have been at a very slow pace, hence the need to investigate the readiness of these institutions with regard to the adoption and use of ebooks.

In view of the above benefits and advantage of electronic books the amount of money spent on the subscription of these resources, it has be observed that these resources are either sparingly utilized or not utilized at all. In their studies, Wogu and Obayi cited in [4] and Madaku identified the challenges that affect the use of e-book to include irregularity of power and internet connections, irregularity of e-book subscription and the need to make e-books producers to make e-books use friendly.

This research therefore aimed to find out the institutional preparedness of libraries in Nigeria university libraries to use ebook to provide service for their clients. 
This research is hinged on the theoretical framework of Technology Acceptance Model (TAM) which was provided by [7]. This theory is appropriate for this work as it is an information system theory that describes how users come to accept or reject the use of a technology. Users according to this theory have a choice in the acceptance and rejection of technology depending on how the technology affects them. According to this theory, the decision on the acceptance or rejection of the technology is influence by two critical factors.

The first factor is perceived usefulness (PU) of the technology, this is the degree to which the user believes that using electronic book or an online database or a technology would enhance his or her academic task.

The second factor according to [7] is perceived ease of use of the technology. This is seen as the degree to which the use of technology cannot be cumbersome but with minimal effort. The author argued that technologythat requires the possession of complicated skills may not easily attract users. Both factors perceived usefulness and perceived ease of use affect people's decision to use new technology thereby contributing to either acceptance or rejection.

In this present study, the theory would explain both the institutional readiness and use of electronic books in information provision for the academic in university libraries in Nigeria.

\section{OBJECTIVES OF THE STUDY}

The broad objective of the study is to determine the readiness and use of electronic books for information services provision in university libraries in Nigeria.

The specific objectives include to:

a. Ascertain the institutional readiness for information service provision and use of electronic books in the universities understudy.

b. Determine the perceived usefulness of electronic books in information services provision in the universities understudy.

\section{RESEARCH QUESTIONS}

The following questions guided this study.

1. What is the institutional readiness for information service provision and use of electronic books in the universities understudy.

2. What is the perceived usefulness of electronic books in information service provision in the universities understudy.

\section{METHODOLOGY}

The research method adopted for the study is survey design. The population comprised 636 libraries from twelve universities involved as sample for this study. The sample was purposively determined by the use of e-book presence of the university library. To arrive at this a preliminary survey conducted to ensure that all the university libraries selected have electronic books in their collections.

Questionnaire was used as instrument for data collection. This survey method effectively elicited information of the e-books institutional readiness, level of awareness of use and the challenges of using e-books in the universities understudy. While the data collected were analysed with the use of descriptive statistics frequency count, mean and percentages. 
Table 1 Frequency Distribution of Respondents by University

\begin{tabular}{|l|l|l|l|}
\hline S/N & University & Frequency & Percentage \\
\hline 1 & Covenant University Library & 32 & $5.0 \%$ \\
\hline 2 & University of Ibadan Library & 96 & $15.1 \%$ \\
\hline 3 & Federal University of Petroleum Library & 28 & $4.4 \%$ \\
\hline 4 & University of Port-Harcourt Library & 56 & $8.8 \%$ \\
\hline 5 & Bayero University Library & 76 & $11.9 \%$ \\
\hline 6 & Umaru Musa Yar'adu University Library & 44 & $6.9 \%$ \\
\hline 7 & University of Nigeria, Library Nassuka & 88 & $13.8 \%$ \\
\hline 8 & Federal University of Technology Library Owerri & 52 & $5.2 \%$ \\
\hline 9 & University of Maiduguri Library & 32 & $7.5 \%$ \\
\hline 10 & UsmanuDanfodiyo University Library Sokoto & 48 & $7.5 \%$ \\
\hline 11 & Benue State University Library Makurdi & 48 & $5.7 \%$ \\
\hline 12 & Salem University Lokoja Library & 36 & $\mathbf{1 0 0 \%}$ \\
\hline & TOTAL & $\mathbf{6 3 6}$ & \\
\hline
\end{tabular}

\section{Responds Rate of Respondents}

A total of 636 sets of questionnaire were distributed and 420 copies representing a response rate of $66.1 \%$ were returned. This response rate of $66.1 \%$ consideration adequate for this study in view of the wide spread of respondents.

\section{Table II}

Research Question 1: What is the level of institutional readiness for the use of electronic book libraries. Where less than 50 percent agreement is low level and above is high level

\begin{tabular}{|l|l|l|l|l|l|l|}
\hline Statement & SA/A & Percentage & SD/D & \% & Total & \% \\
\hline $\begin{array}{l}\text { ICT facilities are readily available for the use of } \\
\text { e-books in the library. }\end{array}$ & 18.9 & 192 & 91.4 & 210 & 100 \\
\hline $\begin{array}{l}\text { There is enough space in the library for the } \\
\text { storage of electronic books }\end{array}$ & 136 & 64.7 & 74 & 35.2 & 210 & 100 \\
\hline $\begin{array}{l}\text { There is internet connectivity in the library for } \\
\text { the use of electronic books }\end{array}$ & 10.4 & 188 & 89.5 & 210 & 100 \\
\hline $\begin{array}{l}\text { There is equipment like air-conditioner in the } \\
\text { library for the preservation of electronic books }\end{array}$ & & 57.6 & 79 & 42.4 & 210 & 100 \\
\hline $\begin{array}{l}\text { There is management policy which supports the } \\
\text { use of electronic books for information provision } \\
\text { and service in the library. }\end{array}$ & 33 & 15.7 & 177 & 84.2 & 210 & 100 \\
\hline $\begin{array}{l}\text { The library has sufficient skilled manpower to } \\
\text { man the electronic books facilities }\end{array}$ & 48 & 22.8 & 162 & 372 & 210 & 100 \\
\hline
\end{tabular}




\begin{tabular}{|l|c|c|c|c|c|c|}
\hline $\begin{array}{l}\text { There is alternative source of power supply to } \\
\text { ensure regular power supply to use the e-nooks }\end{array}$ & 55 & 26.1 & 155 & 73.8 & 210 & 100 \\
\hline $\begin{array}{l}\text { There is provision for staff training on the use of } \\
\text { electronic books facilities. }\end{array}$ & 88 & 41.3 & 122 & 586 & 210 & 100 \\
\hline
\end{tabular}

From the finding in table II it is clear that the level of institution readiness with regard to most of the items in the questionnaire is low. On the available of ICT facilities in the university libraries under study, 192 of the respondents representing 91.4 percent ranked it low. The same is true of availability of internet connectivity which ranked second low with 188 respondents represent $89.5 \%$ indicating it. Management support for the use of electronic books in the university libraries ranked third low with 177(84.2\%)of the respondents indicating it while lack of skilled man power which ranked fourth low was indicated by 162 representing (77.1\%) of the respondents. The issue of alternative source of power supply for the use of electronic book facilities ranked fifth low with $155(75.8 \%)$ of the respondents indicating it. The sixth in the low level ranking is the provision of staff training on the use of web 2.00 tools. This was indicated by 122 representing 58.6 percent of the respondents.

However only two items on the table recorded high levels of institutional readiness. With more than $50 \%$ agreement. These include the issue of space in the libraries for the storage of e-books facilities this was indicate first high by 136 representing (64.7\%) of the respondent, while the issue of equipment like Air conditioners etc was indicated second high with 121 representing 57.6 of the respondents indicating it. From the analysis above it is very clear that the institutional readiness of the university libraries understudy is low. The reason for this is not unconnected with the fact that ICT facilities for the use of electronic books is capital intensive and would therefore need institutional will on the part of the universities to meet it.

\section{Table III}

Research Question 3: What is the perceived usefulness electronic book in information service provision. Useful statements frequency/percentage

\begin{tabular}{|l|c|c|c|c|c|c|}
\hline Statement & SA/A & Percentage & SD/D & \% & Total & \% \\
\hline $\begin{array}{l}\text { The use of e-books bridges time and space in } \\
\text { information services provision }\end{array}$ & 162 & 77.1 & 48 & 22.8 & 201 & 100 \\
\hline $\begin{array}{l}\text { The use of e-books minimizes cost and efforts in } \\
\text { information service provision }\end{array}$ & 155 & 73.8 & 55 & 26.1 & 201 & 100 \\
\hline $\begin{array}{l}\text { The use of e-books in information services } \\
\text { provision maximize quality }\end{array}$ & 136 & 64.7 & 74 & 35.2 & 201 & 100 \\
\hline $\begin{array}{l}\text { The use of e-book maximize efficiency and } \\
\text { effectiveness }\end{array}$ & & 57.6 & 79 & 42.4 & 201 & 100 \\
\hline
\end{tabular}


From the analysis in table III about the usefulness of e-books in information services provision, majority of the respondents agreed that e-books are useful for information services provision in their libraries.

Their positions are corroborated in a study by Alabi cited in [8], which argued that whenever technology intervenes in human activities, the essential feature is how to bridge time, space, to minimize cost and efforts as well as maximize quality, efficiency and effectiveness: PI. The findings in the study are also in line with the position of [9], who augued that with the ability to retrieve remotesources onthe internet, it is now possible to provide the needed information when the need is made manifest. This is also in line with the position of Hangging and Sinate (2012) who argued that the preference for the use of electronic books for information service provision occasioned by new technologies is because of their easy of accessibility and use.

\section{CONCLUSION}

This study set out to determine the readiness and use of electronic books for information service provision in university libraries in Nigeria. Survey research design was adopted for this study. A multi-stage sampling technique was used to select two universities from each of the six geopolitical zones base on the presence of ebooks in the university libraries.

Questionnaire was used as instrument for data collection while the data collected were analysed with the use of descriptive statistics (frequency count, mean and percentage).

The study revealed that the level of readiness of the institutions for the use of e-books in the university libraries understudy is low. This is evident in the lack of ICT facilities in the university libraries studied. On the perceived usefulness of e-books in information service provision, majority of the respondents agreed that ebooks are useful for information service provision in their university libraries

\section{RECOMMENDATIONS}

The following recommendations have been made base on the findings

1. The university administrations should show more political will by increasing financial resource available to the university libraries to enable them to acquire moreICT facilities especially e-book readers.

2. Training programmes should be organized for the library staff to acquire skills in the use of electronic books, and also enhance their ICT skills in general.

3. The universities should provide alternative sources of power supply to use the electronic book facilities.

4. There should be internet connectivity in the university libraries to enable staff and users to use electronic book. 


\section{REFERENCES}

[1]. R. Sasson, (2017) The benefits and advantages of e-book. Success consciousness tools for prosperity, positivity and peace. www.successconcousness.com visited 20thJuly, 2017.

[2]. M. Vassilion, and RowlEy J. (2008) Progressing the definition of e-book. Library Hi Tech 25(3)

[3]. M. Ronse (2017) E-book Whatis.com visited April 21, 2017

[4]. F Okocha,(2016) Student acceptance of e-books: a case study of Landmark university. The Information Technologist: An international Journal of Information and Communication Technology 13 (2).

[5]. D, Nicholas, Huntington, P. and Rowlands I. ( 2007) E-Books: how are the users responding. Library and Information Update 6(11)

[6]. M.A Bello, Barkin, S.F and Lawal, Mohammed (2018) Usage of e-books in Nigerian university libraries: The circulation librarian's experience. The Information Technologist: An International Journal of Information and Communication Technology 15(2) 63-74.

[7]. F.D Davis (1991) Paceived usefulness, perceived Ease of use and user Acceptance Information Technology. MIS quarterly, 13 (3).

[8]. E.C Madu, and T.N Ademiran (2005) Information Technology: Uses and presentation of resources libraries and information centres, Ibadan; EVI-Coleman.

[9]. A.O. Scott-Emuakpor, (2000) Impact of information technology on collection development and management in libraries in Madu E.C and M.B Diriso (eds) Information Science and Technology for Library Schools in Africa, Ibadan: EVI-COLEMAN. 